\title{
Some cases in the Masorah of Spanish Manuscripts
}

\author{
M. ${ }^{a}$ Teresa OrtegA-MonAsterio \\ CSIC, Madrid
}

On several occasions, I have demonstrated the high quality of the Spanish manuscripts, specifically the manuscript M1 (118-Z42) of the University of Madrid. As I said, the manuscript M1 is being studied by the Hebrew Bible Team at the Philology Institute in Madrid. We intend to publish its Pentateuch masorah in the next year. This manuscript served as one of the basis texts for the Complutensian Polyglot edited by Ximenez de Cisneros in the 16th century, and has been considered as one of the best for the Polyglot composition. In his Introduction to the Massoretico-Critical Edition of the Hebrew Bible (New York 1966, p. 775), Ginsburg described it as a «magnificent codex», and affirms that it has served as a guide for the compilers of the Polyglot.

But not only the manuscript M1 has a high consideration among Spanish codices. In El Escorial Library, there is another manuscript, the G-II-8, which has been described by J. Llamas ${ }^{1}$. According to his oppinion, it was also used for the Complutensian Polyglot text composition. We know that it belonged to Arias Montano's manuscript collection. He was the first director of the El Escorial Library and editor of the second Polyglot or Biblia Regia, published between 1569 and 1572 at the Plantino press in Antwerp, in eight folio volumes. This Bible includes the Hebrew text with Aramaic targumim, the Septuagint, the Peshitta (each with a Latin translation), as well as the Vulgate, the New Testament in Latin, Greek and Syriac, and three volumes of critical

\footnotetext{
${ }^{1}$ José Llamas, Catálogo de los manuscritos hebreos de la Real Biblioteca de
} San Lorenzo de El Escorial (El Escorial 1944). 
notes, vocabulary, comments and excursuses, most of which were written by Arias Montano.

The manuscript G-II-8 consists of 386 folios and contains the whole Hebrew Bible, except two folios containing Gen 38,2442,16 . It is written in a Sephardic handwriting, in two columns, with a rich colourful illumination: gold, silver, blue and red. It has geometrical and floral designs, in the text and the masorah. Only the Pentateuch has masora, parva and magna, but it is particularly rich. In the rest of the books the sĕdarîm and parašiyyôt $\underline{t}$ are indicated. It has no colophon and its date of composition and the name of the scribe are unknown, but it has been dated in the 15th. century. As we shall see in the following examples, it sometimes preserve some masorahs different from the traditional ones; these are the most usual masorahs contained in the old tiberian manuscripts, such as Leningrad (L), Or 4445, Cairo (C) or Aleppo (A) ${ }^{2}$. In some cases, the masorah of G-II- 8 agrees with the masora of M1. In these cases the Spanish manuscripts give information different from that of the tiberian manuscripts or they simply give more specific information. Let us see now some examples.

Spanish manuscripts give sometimes an information different from that of other codices. In Gen 49,22, referring to the word

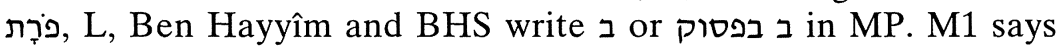

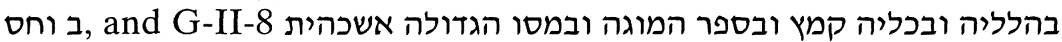
'In the Sefer Hil.leli, all cases are with qames -two in the verse- but in the Sefer Muggah and the masorah magna they have a patah «so that you may obtain a teacher of righteousness» [Hos 10,12]'. Or 4445 has no masorah.

In this case, the Spanish codices do not refer to the number of cases in which the word פị appears, but to the vocalization of the word: to the holem in the first case and to the qames in the second. They add information about the masorah and model codices, and also say that the vocalization of the Spanish codices agree with one of them, the Hillelî. I have to remark that the style of GII- 8 masorah is not the traditional, laconic and cryptic style. The masorah refers to a biblical passage, Hos 10,12, to give an unusual information, which is not the style of the masorah we are accus-

${ }^{2}$ As we know, L represents codex B19a from the Public Library in Leningrad, $\mathrm{C}$ is the Cairo Codex of the Prophets, A is the Aleppo Codex and Or 4445 is the famous Pentateuch of the British Museum. 
tomed to. The masorah suggests that the patah vocalization is erroneous.

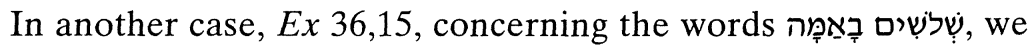
find $T$ in MP in most texts (L, BHS and Ben Hayyîm); Or 4445 and GII-8 have no masorah and in M1 we only read: דוגין מתחלפין. This masorah explains that the four passages are two pairs of parallels: on one hand Ex 26,8 and 36,5 and on the other hand 1 Kings 7,23 and $2 \mathrm{Chr} 4,2$.

The masorah in Gen 1,9 refers to the word וֶר only case written with conjunctive waw, and there are other two cases written תרֶֶ, without the particle. But this is also the only case without dageš in the $\pi$. L and BHS have $ל$ in MP. Ben Hayyîm notes something more specific: ל רפי. Or 4445 has no masorah in Genesis, and in the case of Leviticus it writes $ב$ in MP. Both Spanish manuscripts give more information about this word. M1 says: ל וחד תראה עוד, and it gives the siman of another passage, Lev 13,57, in which the word is written without the conjunctive 1. The masorah does not refer to $I s 47,3$, which is also תִּר , because probably mentiones only the cases in the Torah. Lastly, G-II-8 notes: ל רפי ומלי and inform, not only that the case is, but that this case has rafeh in the $\pi$, whereas the other two cases, Is 47,3 and Lev 13,57, have a dages in the same letter. The manuscript writes the word plene, with final ה. Once again, in G-II-8 we find more information than in the other codices.

Regarding another case, Gen 18,17, and concerning the word

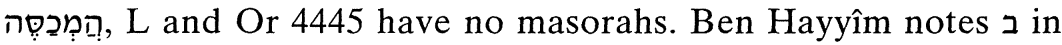
MP, and in BHS Weil explains ב וכל הכליות דכות (this is one of the two cases of this verbal form, and all references to covering the kidneys involves the same verbal form). The second passage is $P s$ 147,8 . But Ben Hayyîm does not note that in one of the two cases the $ה$ is the interrogative particle and in other one is the definite article. The same masorah appears in Frensdorff ${ }^{3}$.

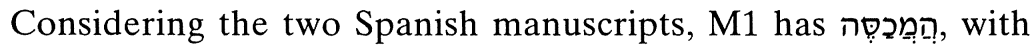
hatef patah instead of šěwa', and notes ${ }^{4}$ וכל החלב המכסה את הקרב כות in MP. G-II-8 has a different MP, and gives information about

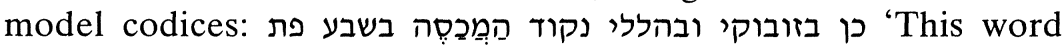

\footnotetext{
${ }^{3}$ S. Frensdorff, The Massorah Magna (New York 1968) p. 101.
}

${ }^{4}$ This passage corresponds to Ex 29,22, and Lev 3,3.9.14. 4,8 and 7,3. 
appears in this form in the Zanbuki but is with šěwa' patah in the Hil.lelì'. It is remarkable that the vocalization given by that masorah agrees only with that of M1. However, if we compare the reading for the Hil.leli with that of the manuscript of the Jewish Theological Seminary known as Codex Hil-lelî (44a), there is no such coincidence, because in the latter the word is vocalized with $\check{s} \check{e} w a$ '.

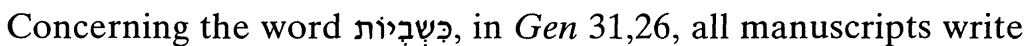
ל ל וחס וא קדמא (the MP and so does Ben Hayyîm. M1 says word is once defective of the first waw) and G-II-8 writes the word doubly defective in the text and notes סא כשביות (other manuscripts plene) in MP.

In Gen 2,19, concerning the word ?ִ ? L L in MP and ב ב חד ח וחד מל WHS. In fact, the word occurs two times, one plene (Gen 2,7) and one defective. Ben Hayyîm gives a

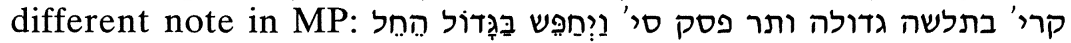

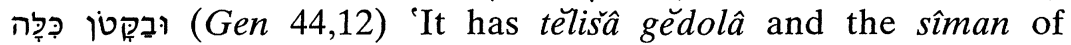
another verse is ...'; he notes the accent of the word and gives the siman of another passage. Referring to the case of Gen 2,7, M1 writes ביו חב הדין חס וקדמ מל MP and G-II-8 writes MP.

The manuscripts sometimes give in its MP an information different from that of the MM. For instance, concerning the word in Zeph 1,1, we find two masorahs: $\lambda$ in MM or יב לפ in MP. Weil ג לפי מג וחד מן יב לפי מק : explains this masorah in BHS as follows 'one of the three occurences according to the masorah gédolâ and one of the twelve occurrences, according to masorah qétana ${ }^{\prime}{ }^{6}$. I have found this entry in no one of the manuscripts I have consulted. In these codices we find another formulation: $\lambda$, and then they draw attention to the rest of the cases by stating that all of the occurrences of same way, with the exception of one case, $2 \mathrm{Kgs} 18$,9, which writes חזיהו This masorah is found in the Aleppo Codex as follows:

${ }^{5}$ Biblia Hebraica Stuttgartensia. Ediderunt K. Elliger et W. Rudolph, Textum Masoreticum curavit H. P. RÜGER, Masoram elaboravit G. E. WEIL (Stuttgart 1977) p. 3.

${ }^{6}$ G. WEIL, Massorah Gedolah (Roma 1971). Nevertheless, in his list 3125 he gives Neh 7,21 instead of Neh 10,18 as the third siman of Arn. And he gives the second list, 3983 as if L had MM in the passage of Neh, which is wrong. In this passage $\mathrm{L}$ has no MM and writes ב in MP, corresponding to the word לחזקיה. 


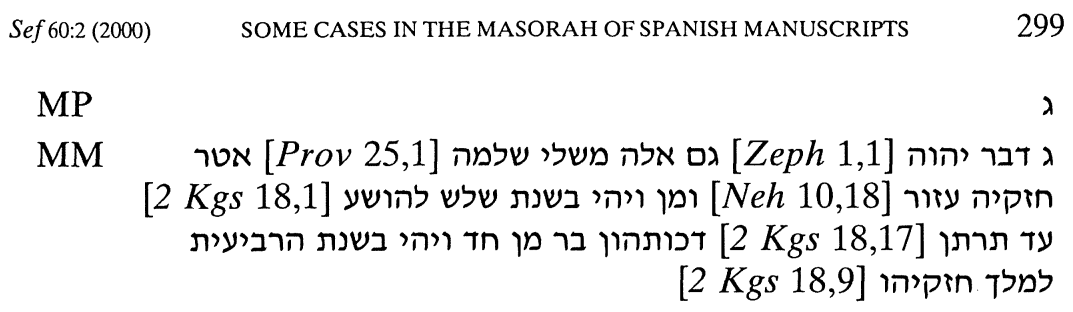

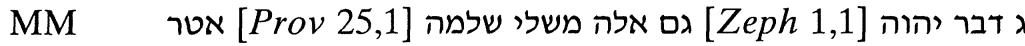

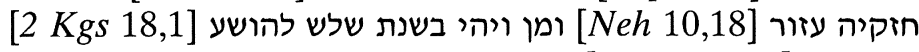

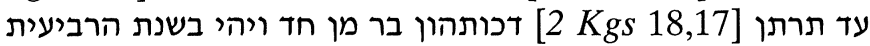

למלך חזקיהו [2 Kgs 18,9]

In Kings this name occurs 37 times in total. In this book, the longer form occurs 36 times and the shorter form only one time. In this case, the masorah safeguards the solitary exception. L and C only say $\lambda$ in MP, and Ben Hayyîm's edition and M1 give the complete masorah and write the first three simanim as well as the exceptional passage of Kings. Once again, we find that a masorah of one of the Spanish manuscripts clarifies the problem better than those of other codices, although this word is also problematic ${ }^{7}$.

In Spanish manuscripts we sometimes find information which is clearly not taken from the traditional sources, as it is the case of Gen 25,6, concerning the word הִּילְגְשִים. L notes ל ומל in MP, which is not totally correct, because there is another plene case in Est 2,14. It probably refers to the only case in the Pentateuch. The second occurrence in Esther has no masorah. Weil has corrected this masorah in BHS and notes ב מל ול בתור, including both possibilities.

Ben Hayyîm has ב מל דמל שומר in MP, and gives the sîman of the second passage, שומר. He explains that the word must be plene in both instances, in the פי פי and in the 4445 has no masorah.

Now we take a look to the Spanish codices. M1 has הַפְּילְגִשֶם in the text, with the $w$ defective and notes (without circellus) MP. The other case, Est 2,14 is doubly plene and without masorah. In G-II-8 we find a different MP: איבא פלוגת עלה בספרים מדוייקי אשכחת 8 there is a discrepancy in this case: I have found the word written without the last yô $\underline{d}$ in correct codices and it will be not corrected until Eliahu shall come'. It explains that the M1 text is also correct, even though it

\footnotetext{
7 Vid. Ch. D. GinsBurg, The Massorah, vol. IV, p. 378, § 121. He has found six different lists in the collated manuscripts, some of them agree with the notes found in $\mathrm{M} 1$ or $\mathrm{A}$.

8 'Until Eliyahu shall come', it is, for an indefinite space of time. Vid. M. JAstrow, A Dictionary of the Targumim, the Talmud Babli and Yerushalmi, and the Midrashic Literature (New York 1967) vol. I, sub voce אליהו.
} 
always appears plene in the other tiberian codices. And it also explains that the variant reading, if we only refer to one of the two plene/defective occurrences, is the second one, in the $w$. This specification is not found in any of the other manuscripts ${ }^{9}$.

We also find information in Spanish manuscripts in cases where the other codices have no masorah. For instance, in Gen 1,4 and 1,12, concerning the words כי טוב, neither L, Or 4445, BHS, Ben Hayyîm or G-II-8 have masorah. M1 is the only manuscript which says ו ו בענינו MP and gives the simanim in MM as follows:

וירא אלהים את האור כי טוב [Gen 1,4] ויקרא אלהים ליבשה ארץ ולמקוה המים קרא מים [Gen 1,10] ותוצא הארץ רשא [Gen 1,12] ולמשל ביום וברים ובלילה

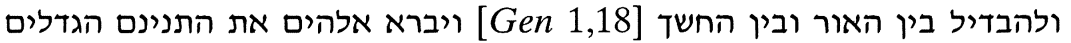
] 1, ויעש אלהים את חית הארץ למינה ואת הבהמה למינ [Gen 1,21, [Gen]

In the masorah of Gen 30,19 regarding the words בן-שִשר, we find different information in the manuscripts, although all of them refer to the vocalization of the word בן, depending on whether it is followed by maqqef or not. This noun is normally vocalized with sĕgôl in the construct form joined by maqqef, except in four instances where it is anormally joined with sêreh.

L has no MM and writes ד מקף in MP. The four occurrences are located in the MM of other manuscripts. These are Gen 30,19, 1 Sam 22,20, 2 Sam 9,12, and $E z 18,10$. L has no masorahs in the two cases of Samuel and writes 7 without MM in Ezequiel.

Or 4445 has no masorahs in this passage, but in Lev 24,10 we find another masorah referring to

MP

\footnotetext{
${ }^{9}$ Commentators explain that, depending on whether the second $y \hat{o} \underline{d}$ is written or not, they refer to only one of Abraham's wives (Agar and Qeturah) or to both of them. In Sefer Beresit Rabbâ (Vilna 1884) cap. 61, §4, p. 122a it is defective and they interpret that it refers to only one of them.
} 
It says $>$ in MP and reads «six times with sĕgôl» in MM, gives the six simanim, and specifies the exception of the four cases with șêreh.

Ben Hayyîm gives also two peculiar notes in Gen 30,19. He writes חד מן ד' מקפין וקמץ in MP, in MM explains thath maqqef is vocalized with segôl except in four cases, and he then gives the simanim. It continues to say that if nûn is vocalized with șereh, except in seven cases, and he also gives the simanim.

MP חד מן ד' מקפין וקמץ

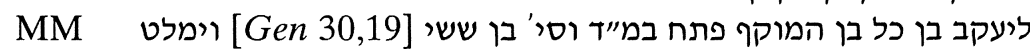

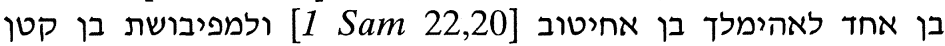

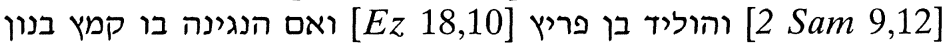

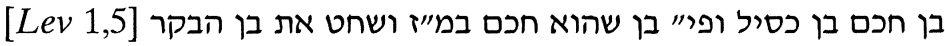

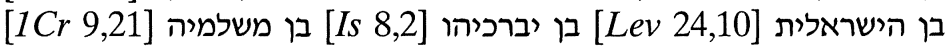
בן יאיר [Est 2,5] בן משלם [many passages] בן ברכיה [24.

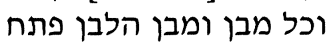

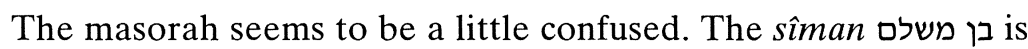
likely to refer to more than one passage ( $2 \mathrm{Kgs} 22,3$; Neh 11,7; $11,11 ; 1 \operatorname{Chr} 9,7 ; 9,11 ; 9,12)$, but not to the one which is supposed to do, namely Gen 17,17 . We find the same problem in (Prov 17,25 or 19,13) and in (1 Kgs 5,21; Prov 10,1; 15,20; $13,1 ; 2 \mathrm{Chr} 2,11)$. It is not clear if the vocalization must be under the bêt or under the nûn. The masorah omits the case of Gen 17,17, and gives the siman בן משלם. In the Masorah Finalis, Ben Hayyîm gives also another note too: בן ז בטע פתחי וסימ נמסר בפרשת ויצא וע"ש. This masorah can also be found in Gen 17,17.

Let us see now the situation in the Spanish manuscripts. M1 has two masorahs in Gen 30,19. The first one corresponds to the

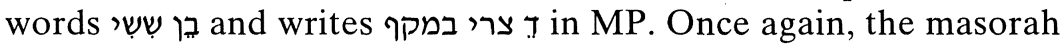
protects the minority reading. The second note corresponds to the word 17 and gives the four simanim in MM:

בן ד קמצין במקף וסימנהון ותלד בן ששי ליעקוב [Gen 30,19] ולמפיבשת בן קטן ושמו מיכא [Sam 9,12] וימלט בן אחד ושמו מיכה [Ez 22,20]

בן פריץ [Ez 18,10

The manuscript G-II-8 has no masorah in its corresponding page, but another very famous Spanish codex, the Or 2626-28 of the British Museum has also two masorahs in Gen 30,19. The first 
one, corresponding to the words בן שִ שִ במק in MP, and the second one, corresponding to the word בן, writes the four simanim in $\mathrm{MM}$ and adds the seven cases where the $ב$ is vocalized with ségôl because of the accent as follows:

ליעקב ד קמ במק וסימנהון ותלד בן ששיא [Gen 30,19] וימלט בן אחד

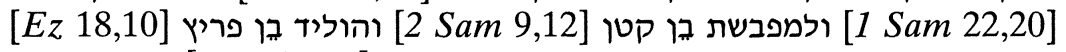

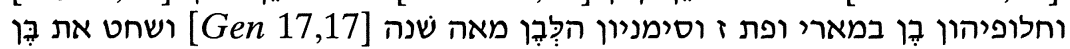

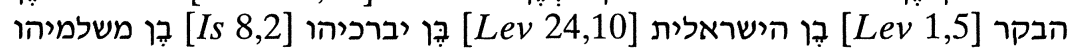

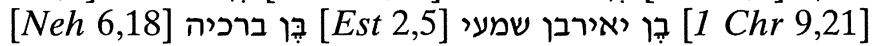

The Cairo codex has no reference to this case, neither in Samuel, nor in Ezequiel. In the MP of 2 Sam 9,12 Aleppo notes that there are four cases with maqqef and sêreh, and gives the sîmanîm in MM:

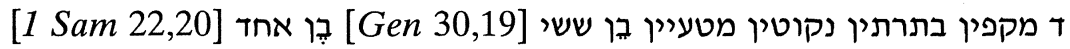
בן קטן [Ez 18,10]

In the other cases it has no masorah.

About these two different informations, Frensdorff ${ }^{10}$ explains: « with accent (without maqqef) is vocalized with sêreh, except in six or seven cases, where it is vocalized with ségôl. On the contrary, when has no accent but maqqef, it is vocālized with sĕgôl, except in four cases where is vocalized with sêreh». Concerning the first masorah, the six or seven cases depend on whether the word has a prefix or not (in case Gen 17,17 is included or not).

We find more information about this issue in Yědidyah Shĕlomoh de Norzi's Minhat Šay. In his comments on Gen 30,7 he writes: שפחת רחל בן שני ליעקב": The bêt with sêreh in the correct codices and without maqqef, as in בן שני ליעקב, which is close to this one (Gen 30,12). In the Miqrah Gédôlah it appears with sêreh and maqqef and says: בן with maqqef has always patah (explanation: with ségôl), except in four instances. The maqqef is erroneous and what is here written corresponds to another passage, בן ששי in Gen 30,19 , as is written in the masorah».

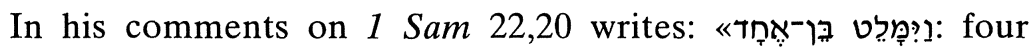
times with șêreh and maqqef, and its sîmanîm are ותלד בן ששי ליעקב ולמפיבשת בן קטן az 18,10) והוליד בן פריץ (Een 30,19); 1 Sam 22,20) (2 Sam 9,12)».

Finally, in $E z$ 18,10 Norzi says: «In a manuscript codex the $b \hat{e} \underline{t}$ is

${ }^{10}$ S. FrensdorfF, Massorah Magna (New York 1968) p. 35, בן, note 2. 
vocalized with sĕgôl but this is not correct, as the masorah of the parasâ ויצא (Gen 30,19$)$ says, because this passage is one of the four cases vocalized with șêreh».

In the examples I have analyzed, we notice differences in the information given in the codices on the same cases. In some cases, the notes simply give the same information but written in a different form. In other occasions, the differences can be explained by many reasons. They may come from different traditions, or be taken from different masoretic lists. We also find two different masorahs with two informations concerning different issues.

The Spanish codices seem to have a very coherent method in their masorah, even when they offer notices not found in other manuscripts. In these cases, they are often supported by other masoretic works, such as Minhat Š Šay or Ginsburg's Massorah.

\section{RESUMEN}

En el presente artículo se analizan algunas notas masoréticas del Pentateuco en diferentes manuscritos españoles. Algunos de ellos deben su importancia a que fueron utilizados para establecer el texto base de la Biblia Políglota Complutense de Cisneros. Más adelante, se compara la información de estas notas masoréticas con los manuscritos de Leningrado, Or 4445, Cairo y Alepo y con las ediciones de Ben Hayyîm y Biblia Hebraica Stuttgartensia (BHS) con el fin de demostrar la proximidad de los códices españoles con la tradición tiberiense de Ben Ašer.

\section{SUMMARY}

The present article analyzes some masoretic notes of the Pentateuch of different Spanish Manuscripts, some of them having been used as basis for the Cisneros' Complutensian Polyglot. In order to demonstrate the proximity of the Spanish codices with the Ben Asher tradition, I compare the notes of masorah with those of the manuscripts Leningrad, Or 4445 and Aleppo, and with the BHS and Ben Hayyîm editions as well. 